\title{
An Analysis on Il Fossilization Phenomenon in Students' Writing Performance
}

\author{
Nurul Aini ${ }^{1}$, Muhammad Khoirul Mufid ${ }^{2}$, Eny Maulita Purnama Sari ${ }^{1}$ \\ ${ }^{1}$ Universitas Nahdlatul Ulama Lampung \\ ${ }^{2}$ Sekolah Menengah Atas Baskara Sahad Putra Rumbia \\ Email: nurulaini@unulampung.ac.id
}

\begin{abstract}
This present study tries to investigate the students' writing performance to know whether interlanguage fossilization is occurs or not. The primary goal of this research is to give information relating interlanguage fossilization in students' writing performance of English Education Study Program of IAIN Jurai Siwo Metro. This research is qualitative research. It is used to describe interlanguage fossilization that occurred in students' writing performance. The writer uses observation, documentation and interview to collect the data. Purposive sampling is the technique for choosing the ten students of the sixth and the eight semester of English Education Study Program of IAIN Jurai Siwo Metro in the Academic Year of 2017/2018. The result of this research shows that there are two types of interlanguage fossilization that are commonly produced by students' writing performance. They are syntactical fossilization and morphological fossilization. Syntactical fossilization consists of $71,86 \%$ and morphological fossilization consists of $28,14 \%$. Moreover, interlanguage fossilization phenomenon in students' writing performance is caused by the students' low English proficiency. Therefore, the students should be more active to improve their English ability.
\end{abstract}

Keywords: IL Fossilization, SLA, Syntax, Morphology

\section{INTRODUCTION}

It has been widely recognized that learning English is very significant for Indonesian students because English is one of foreign languages. Moreover, there are four basic skills that should be learned namely listening, reading, speaking, and writing. In this case, writing is one of the important skills to be mastered by the students who are studying English in University.
Concerning with the importance of writing, some universities offer a writing to encourage the student's writing skill such as write sentences, paragraphs, and essays. In Rohmah (2009:12) writing skill covers the mastery of language, mechanical skills, treatment of content, stylistic skills and evaluative skills. Furthermore, writing is a compulsory subject in English language teaching as needed by university students to express their ideas 
both academic and non-academic writing (Maming, Irmayanti, and Nur 2019).

In this case, learners usually face the complexities of writing as a dimension of learning their mother tongue. Then, it also influenced by their native language when they are writing English. This is due to interference in foreign language acquisition. Consequently, they use incorrect linguistic features permanently which causes interlanguage fossilization phenomenon.

Interlanguage fossilization is a term for language learner who frequently applies inappropriate linguistic features. Errors become fossilized when they have become permanently. They are established in the interlanguage of foreign language learner in a form that is deviant from the target language norms. Interlanguage fossilization occurs in second or foreign language acquisition. Many Indonesian students fail to attain their aim of English proficiency which is same as native speaker due to an inability to permanently correct persistent errors.

As noted by Selinker in Fauziati (2011:23) that most of second or foreign language learners fail to reach the same level of target language competence. They often use deviant forms from target language norms permanently. The reason for the occurrence of errors is the difference between the source language and the foreign language. As a result, their target language (TL) always contains errors. In general, such errors are considered as an inevitable sign of human weaknesses, for example, as a consequence of lack of attention, poor memory, or incomplete knowledge of the language on the part of the learners, or inadequacy of the lecturers' teaching.
It can be conclude that interlanguage fossilization is very urgent to be prevented in English language instruction within Indonesian context. It has drawn much attention and commonly acknowledged at home and abroad.

Nowdays, many researchers as relevant as this research. So, the writer done a review of some articles to get the uniqueness of this research. These articles are: firstly, Wei (2008) done a reasearch in IL Fossilization for SLA in China to get the information about the classified the IL Fossilization and known the causal factors of fossilization. There are some causal factors of fossilization, so the writer proposed three fossilization reduction (adoption of proper learning strategies, reduction of negative transfer of L1 and exposure to TL and TL culture) to solve the fossilization problems in all aspect of language. Secondly, Fauziati (2011) focused on the error fossilization-related issue with specific focus on grammatical errors. The result is the grammatical errors are dynamic and not fossiled in the learners. Thirdly, Chen \& Zhao (2013) shown the major causes of fossilization and implieas some teaching methods to lessen its negatives effect. There are five methods to soleve the problems. But, this research mainly analyzed the theoretical level of IL fossiization. Fourthly, Dina (2017) identified the writing errors across EFL postgraduate students. This study reported that almost the fossil errors were of article, grammar, number, relative lauses, and style. This study also proposed a few potential pedagogical implication that help the students to reduce fossilization. 
Based on the previous study, the writer got a gap to conduct a research in interlanguage fossilization in students' writing performance of English Language Study Program in IAIN Jurai Siwo Metro. In this case, the writer focus on grammatiacal and linguistics errors such as error in tenses, syntax, and morphology. In line with the importance of interlanguage fossilization, the writer interested in doing research about interlanguage fossilization phenomenon in students' writing performance of English Education Study Program of IAIN Jurai Siwo Metro in the Academic Year of 2017/2018.

The aims of this research are; First, to find out the types of interlanguage fossilization that created by the students in their writing performance. Second, to investigate some causal factors of interlanguage fossilization in students' writing performance. Third, to give solution for overcoming interlanguage fossilization that occurs in students' writing performance.

\section{LITERATURE REVIEW}

\section{a. Writing Performance}

Terminologically, as it was cited by Jordan (2003:41) stated that writing is method of human intercommunication by means of conventional visible marks. It means that writing is a way to deliver a message from someone to others by written language. Furthermore, Saville and Troike(2006:163) assumed that writing is a common medium for testing knowledge in much of the world-including knowledge of the L2 itself, even within instructional programs that emphasize oral production. It should be noted that writing is a method that used to know second or foreign language students' competence in the target language.

On the other hand, Brown (2000:30) stated that performance is the overtly observable and concrete manifestation or realization of competence. It might be assumed that performance is a real doing of something that shows the competence of people. It can be observed to know the competence of people. Therefore, it can be inferred that writing performance is the ability of people produce a language to communicate each other for any purposes that it includes the physic and mental activities to produce written language.

\section{b. Writing Types}

George E and Burks(1980:128) mentioned four types of writing as follows; first, Description helps the reader through his/her imagination, to visualize a scene or a person, or to understand a sensation or an emotion.Second, Argumentation means supporting one side or the other of a controversial topic. This method is to make a general statement and support it-or sometimes to lead logically to a general conclusion by a series of facts." Third, Narrative is a type in which the writer tries to recount an event (object) of his world experience in order his readers can see, feel, hear, and taste it as he can." Fourth, Exposition is to show the (new) truth of fact an object in order the readers believe or disbelieve something related to the object they are experiencing." 
Nurul Aini, Muhammad Khoirul Mufid, Eny Maulita Purnama Sari

\section{c. Writing Process}

Kane (2000:19) explains several writing steps. Firstly, "thinking," involves choosing a subject, exploring ways of developing it, and devising strategies of organization and style. Secondly, "doing" is usually called "drafting"; and the third is "doing again" is "revising". Furthermore, the explanations of those steps are as follows: The first, Looking for subject related to a writer should have a source in writing. It is because people want to write but they do not know what they will write. Solution for the problem is reading some books and look around. As a result, a writer will inspire and enrich her or his minds. Then, Exploring the topics is to explore the subject to look for the topics before beginning draft. Next, Making a planmeans the writer makes a plan that shows the writer's purposes. Last, Draft and revisions are an early version of a piece of writing. Most of writers cannot compose anything well at the first try. We must write and rewrite. These initial efforts are called drafts, in distinction from the final version. As a rule, the more you draft, the better you get the result. It can be concluded that a writer needs much time to make a good writing. Meanwhile, revision is a procedure for correcting a work in progress. Revision is the final steps of writing. It purposes to re-evaluate the writing. Then, the writer will compose it becoming perfect writing.

\section{d. Types of Writing Performance}

Brown (2003:220) is noted some types of writing performance, such as: Imitative means a student has to obtain skill in the fundamental. Therefore, the students write down what they hear in order to know the mechanics of writing; Intensive (controlled)means students can examine the form of writing. Thus, the students are able to use the form of writing correctly; Responsive means the students are able to perform at limited discourse level, connecting sentences into a paragraph and creating a logically connected sequence of two or three paragraphs; and Extensive shows successful management of all the strategies and processes of writing. The writer focuses on obtaining a purpose, organizing and developing ideas logically, using details to support ideas for achieving a final product.

\section{e. Interlanguage Fossilization}

The term Interlanguagewas popularly by Selinker in 1972. Interlanguage is conceived the product of interaction between two linguistic system, the Native Language and the Target Language. From the quotations, it can be stated that interlanguage is concentrated as the result of interaction between two linguistic systems, the source language and the target language. Second or foreign language students usually produce different language from both source and target language norms.

Moreover, Selinker in Fauziati (2011:30) introduced the term Interlanguage (IL) refers to the intermediate states of a student's language as it moves toward the target language. Then, it shows that language students face interlanguage in attaining the target language. In addition, interlanguage refers to the developmental 
process of the target language learning. A student's Interlanguage is influenced by first language and second language systems. It is clearly accepted, interlanguage itself is as a third language system in which it differs from both first language and second language during the course of its development. For example:

a. IL: *Subject I don't like is physics because is very difficult.

L1: Subject yang tidak saya sukai adalah fisika karena sangat sulit.

b. IL: *My Novel favorite is Harry Potter, I very like it.

L1: Novel favorit saya adalah Harry Potter, saya sangat menyukainya.

On the other hand, Brown (2001:67) argued that second language students tend to go through a systematic or quasi-systematic developmental process as they progress to full competence in the target language. Successful interlanguage developmental is partially a result of utilizing feedback from others.

Furthermore, Skehanin Spolsky and M.Hult (2008:411)argues that "the study of interlanguage and language transfer have been long-standing issues in applied linguistics, he states that interlanguage is a language transfer in which huge importance to the pedagogic domain". Interlanguage is a language transfer which is very important in second and foreign language acquisition. Interlanguage can influence both negative and positive transfer that has a major impact on second or foreign language learning. Positive transfer is transfer which makes learning easier, and may occur when both the native language and the target language have the same form. Negative transfer, also known as interference used of a nativelanguage pattern or rule which leads to an error or inappropriate form in the target language. Therefore, it should inform teaching decisions, and the developmental stages should be incorporated in second language acquisitioninformed account of syllabus design.

From the quotations above, it can be concluded that the concept of an interlanguage as a system of language student which produces a different language both first language and second language. It is highly productive in the study of second language or foreign language. In addition, Interlanguage is a developmental process in learning language; the students' errors are the result of their 'wisdom'. They use their proper knowledge to analogically elaborate new language items. In this case, they think that their new language is correct but it is the opposite of the target language. Therefore, complete ignorance of the language does not cause of their errors.

Selinker1972 in Wei $(2008: 127)$ first put forwarded the notion of fossilization in the paper interlangauge. He noted that $95 \%$ of second language students failed to reach the same level of first language competence from his observation. This kind of phenomenon is defined by Selinkerin Han (2004:15)as fossilization. It can be cited that fossilization is unsuccessful 
student in second or foreign language learning. This is because the students stop learning before achieving the target language competence. So, fossilization is recognized as a widespread phenomenon in second language acquisition for linguistics and language students have been aware that it is extremely rare for the student of a second language to achieve full native-like competence.

Meanwhile, Brown (2007:270) of fossilization differs from Selinker and Ellis as he sees it can be prevented. He uses metaphor of "cryogenation", the process of freezing matter at very low temperatures; to depict the reversibility of fossilization. He assumed that fossilization as a factor of positive and negative affective and cognitive feedback. It means that fossilization can be overcome by giving feedback. Giving a feedback will encourage student to retry, to restate, to reformulate, or to draw a different hypothesis about a rule.

Based on the above quotations, it can be inferred that interlanguage fossilization is the linguistic phenomena which the language students' interlanguage is stabilized permanently. The students frequently use inappropriate linguistic features in the target language. They use incorrect language form permanently before reaching the correct linguistic forms of target language. Furthermore, fossilization is cognitive process in language learning, stabilized interlanguage permanently shows occurring fossilization in the target language learning.

\section{METODE}

\section{Participans}

The writer used purposive sample as the technique of choosing the participants. In the present study, the writer chooses 10 students which had learned writing 4 subject at English Education Study Program of IAIN Jurai Siwo Metro as the participants. It is because they have learned English for a long period. Indeed, they have the English writing products from the first semester up to now.

\section{Method of data collection}

Actually, this research is qualitative. Creswell (2003: 182) defines that the researcher made interpretation of the data. There are two kinds of data sources, namely primary and secondary sources (Ary, 2006: 482). The primary source is the students' speaking product. Then, the secondary source is from books, articles, English dictionary, encyclopedia, and journals that are closely related to the research.

The data was achieved through several techniques, they are: interview and documentation. Documentation is used to collect some information in which has been produced by someone. In this study, the writer used the students' writing performance to support the information that is correlated to the students' interlanguage fossilization phenomenon. The writer had compiled the students' English writing results that were produced on different time or different semester. In this case, the 
writer collected 2 pieces of writing from each participant.

Then, Interview is applied to find out the reason and the solution of interlanguage fossilization in students' writing performance. The writer applied open-ended questions. In the open ended-questions, the writer varied some questions in the form of $5 \mathrm{WH} / 1 \mathrm{H}$ questions that allow the participants answer in free thought, suggestions, and detailed answer.

\section{RESULT}

In this research, the writer had collected 20 writing products that produced by 10 students as the primary data. The writings are the result of students' writing from the different time to find out interlanguage fossilization in their writing. As such, the writer had asked 2 pieces of writing for each student. Furthermore, the writer had interviewed 10 students for supporting the primary data. In presenting the research data, the writer codes the participants to make easiest in understanding the research. The result of the research data briefly will be analyzed in this chapter. The foolowing data are:

\section{Types of interlanguage fossilization}

The writer had found two types of interlanguage fossilization in students' writing performance namely syntactical and morphological fossilization. They are commonly produced by students in their writing. The findings as follows:

\section{a. Syntactic Fossilization}

In this case, the students frequently make errors in syntax. As the result, students always produce the syntactical errors in writing. In the following explanation, the writer would show some errors in the students' writing both in writing 1 and 2. It is to describe syntactical fossilization in students' writing which shown below:

Table 1. Syntactical Fossilization in Students' Writing Performance

\begin{tabular}{|c|c|c|c|c|}
\hline No & Students & Error & Suggested correction & Types of Errors \\
\hline 1. & Std.1 & $\begin{array}{c}\text { Writing } 1 \text { : } \\
\text { In fact, *very important to teach about } \\
\text { Islamic education...... } \\
\text { Writing } 2 \text { : } \\
\text {...beside *have bad effect...... } \\
\text { Writing } 1 \text { : } \\
\text {.....person follow * }{ }^{*} \text { rule of God. } \\
\text { Writing } 2: \\
\ldots . . \text { the body can't take * rest....... }\end{array}$ & $\begin{array}{c}\text { Writing } 1 \text { : } \\
\text { In fact, *it is very important to teach Islamic } \\
\text { education...... } \\
\text { Writing } 2 \text { : } \\
\text {.....beside * they have bad effect..... } \\
\text { Writing } 1 \text { : } \\
\text {.....person follow * the rule of God. } \\
\text { Writing } 2: \\
\text {..... the body can't take * a rest... }\end{array}$ & Word order \\
\hline
\end{tabular}


Nurul Aini, Muhammad Khoirul Mufid, Eny Maulita Purnama Sari

\begin{tabular}{|c|c|c|c|c|}
\hline & & $\begin{array}{c}\text { Writing 1: } \\
\text {....so, life in Metro *make more peace and } \\
\text { wise. } \\
\text { Writing } 2 \text { : } \\
\text {......stay up and talk all night }{ }^{*} \text { is not good } \\
\text { for our health. }\end{array}$ & $\begin{array}{c}\text { Writing 1: } \\
\text {....so, life in Metro *makes more peace and } \\
\text { wise. } \\
\text { Writing 2: } \\
\text {......stay up and talk all night *are not good } \\
\text { for our health. }\end{array}$ & Concord \\
\hline 2 & Std. 2 & $\begin{array}{l}\text { Writing 1: } \\
\text { I have *best friend her name is Lisa Rah- } \\
\text { mawati..... } \\
\text { Writing 2: } \\
\text {...... I have * best friend, her name is } \\
\text { Putri Indah Pratiwi. } \\
\text { Writing 2: } \\
\text { I and *her are studying in campus. }\end{array}$ & $\begin{array}{c}\text { Writing 1: } \\
\text { I have *the best friend her name is Lisa } \\
\text { Rahmawati..... } \\
\text { Writing 2: } \\
\text { Putri Indah Pratiwi. } \\
\text { Writing 2: } \\
\text { She and }{ }^{*} \text { I are studying in campus. }\end{array}$ & $\begin{array}{l}\text { Articles } \\
\text { Pronoun }\end{array}$ \\
\hline 3 & Std. 3 & $\begin{array}{l}\text { Writing 2: } \\
\text { I and *her are studying in campus. } \\
\text { Writing 2: } \\
\text { I and *her are studying in campus. } \\
\text { Writing 1: } \\
\text { *A Metro city that's city of education centre } \\
\text { at Lampung } \\
\text { Writing 2: } \\
\text {..... from the darkness to *lightness. }\end{array}$ & $\begin{array}{l}\text { Writing 2: } \\
\text { She and *I are studying in campus. } \\
\text { Writing 2: } \\
\text { She and *I are studying in campus. } \\
\text { Writing 1: } \\
\text { *Metro city that's city of education centre at } \\
\text { Lampung } \\
\text { Writing 2: } \\
\text {..... from the darkness to *the lightness. }\end{array}$ & $\begin{array}{l}\text { Pronoun } \\
\text { Pronoun } \\
\text { Articles }\end{array}$ \\
\hline 4 & Std. 4 & $\begin{array}{l}\text { Writing 1: } \\
\ldots . . .{ }^{*} \text { still in the third grade senior high } \\
\text { school. } \\
\text { Writing 2: } \\
\text { If you *borred with your activity... }\end{array}$ & $\begin{array}{l}\text { Writing 1: } \\
\ldots . . . I^{*} \text { am still in the third grade senior } \\
\text { high school. } \\
\text { Writing 2: } \\
\text { If you *are bored with your activity.... }\end{array}$ & Word order \\
\hline 5 & Std. 5 & $\begin{array}{c}\text { Writing } 1 \text { : } \\
{ }^{*} \text { I am and my sister helps my mother.... } \\
\text { Writing } 2 \text { : } \\
\text { Afidah and *me ever went to warnet ...... }\end{array}$ & $\begin{array}{c}\text { Writing 1: } \\
\text { * My sister and I help my mother.... } \\
\text { Writing 2: } \\
\text { Afidah and *I ever went to warnet ...... }\end{array}$ & Pronoun \\
\hline
\end{tabular}




\begin{tabular}{|c|c|c|c|c|}
\hline & & $\begin{array}{c}\text { Writing 1: } \\
\text {.... We found name card that * have the } \\
\text { wallet. } \\
\text { Writing 2: } \\
\text { She *is very frightened with her father, } \\
\text { because came late back to home. } \\
\text { Writing 1: } \\
\text {....we went to the market to *bought a gift. }\end{array}$ & $\begin{array}{l}\text { Writing 1: } \\
\text {.... We found name card that *had the wal- } \\
\text { let. } \\
\text { Writing } 2 \text { : } \\
\text { She * was very frightened with her father, } \\
\text { because came late back to home. } \\
\text { Writing 1: } \\
\text {.... we went to the market to *buy a gift. }\end{array}$ & Concord \\
\hline 6 & Std. 6 & $\begin{array}{c}\text { Writing 1: } \\
\text { Sharing *each others burdens and joys...... } \\
\text { Writing 1: } \\
\text {... And if you are one of those people, *I } \\
\text { hate you. } \\
\text { Writing 1: } \\
\text { Love isn't exactly a feeling, now is it? When } \\
\text { you *chose to love someone... } \\
\text { Writing } 2 \text { : } \\
\text {....It will *broke our country. } \\
\text { Writing 2: } \\
\text {...... * she I difficult to sleep. }\end{array}$ & $\begin{array}{c}\text { Writing 1: } \\
\text { Sharing *each other burdens and joys...... } \\
\text { Writing 1: } \\
\text {... And if you are one of those people, *I will } \\
\text { hate you } \\
\text { Writing 1: } \\
\text { Love isn't exactly a feeling, now is it? When } \\
\text { you *choose to love someone... } \\
\text { Writing 2: } \\
\text {....It will *break our country. } \\
\text { Writing 2: } \\
\text {...... * she and I are difficult to sleep. }\end{array}$ & $\begin{array}{l}\text { Singular noun } \\
\text { Conditi-onal } \\
\text { sentence } \\
\text { Verb }\end{array}$ \\
\hline 7 & Std. 7 & $\begin{array}{c}\text { Writing 1: } \\
\text { English is *international language. } \\
\text { Writing 2: } \\
\text { She is *very beautiful woman and graceful. } \\
\text { Writing 1: } \\
\text {.... English *has learned. } \\
\text { Writing 2: } \\
\text { Mother can * to be a friend..... }\end{array}$ & $\begin{array}{c}\text { Writing 1: } \\
\text { English is *an international language. } \\
\text { Writing 2: } \\
\text { She is *a very beautiful woman and graceful. } \\
\text { Writing 1: } \\
\text {....English *has been learned. } \\
\text { Writing 2: } \\
\text { Mother can * be a friend..... }\end{array}$ & $\begin{array}{c}\text { Articles } \\
\text { Passive voice } \\
\text { Concord }\end{array}$ \\
\hline 8 & Std. 8 & $\begin{array}{c}\text { Writing } 1 \text { : } \\
I \text { *leaved at half eight a clock. } \\
\text { Writing } 2 \text { : } \\
\text { He *able to sing a song...... }\end{array}$ & $\begin{array}{c}\text { Writing 1: } \\
I * \text { left at half eight a clock. } \\
\text { Writing 2: } \\
H^{*}{ }^{*} \text { is able to sing a song...... }\end{array}$ & Verb \\
\hline
\end{tabular}




\begin{tabular}{|c|c|c|c|c|}
\hline & & $\begin{array}{l}\text { Writing 1: } \\
\text { I saw much scenery }{ }^{*} \text { is very beautiful.... } \\
\text { Writing 2: } \\
\text {..., but he still *become amazing man. } \\
\text { Writing 1: } \\
\text { I direct to going *beach for swimming... } \\
\text { Writing 2: } \\
\text { He is *amazing man. }\end{array}$ & $\begin{array}{c}\text { Writing 1: } \\
\text { I saw much scenery * was very beautiful.... } \\
\text { Writing 2: } \\
\text {..., but he still *becomes amazing man. } \\
\text { Writing 2: } \\
\text { I direct to go *the beach for swimming... } \\
\text { Writing 2: } \\
\text { He is * an amazing man. }\end{array}$ & Concord \\
\hline 9. & Std. 9 & $\begin{array}{l}\text { Writing } 1 \text { : } \\
\text { One day, after pass national examination of } \\
\text { the senior high school *I and my friends. } \\
\text { Writing } 2 \text { : } \\
\text { My parents always advised * that ...... } \\
\text { Writing } 1 \text { : } \\
\text { Then we *did read qur'an.... } \\
\text { Writing } 1 \text { : } \\
\text { They pick me up to * registered.... } \\
\text { Writing } 2 \text { : } \\
\text {....we * not go so far from my house. }\end{array}$ & $\begin{array}{l}\text { Writing } 1 \text { : } \\
\text { One day, after pass national examination of } \\
\text { the senior high school * my friends and me. } \\
\text { Writing 2: } \\
\text { My parents always advised *us that ...... } \\
\text { Writing 1: } \\
\text { Then we *read qur'an.... } \\
\text { Writing } 1 \text { : } \\
\text { They pick me up to *register.... } \\
\text { Writing } 2 \text { : } \\
\text {... we * did not go so far from my house. }\end{array}$ & $\begin{array}{c}\text { Verb } \\
\text { Concord } \\
\text { Word order }\end{array}$ \\
\hline 10 & Std. 10 & $\begin{array}{c}\text { Writing 1: } \\
\text { It took *very much ours. } \\
\text { Writing 2: } \\
\text { God *help them.... }\end{array}$ & $\begin{array}{c}\text { Writing 1: } \\
\text { It took *many hours. } \\
\text { Writing 2: } \\
\text { God *helps them.... }\end{array}$ & $\begin{array}{c}\text { Plural noun } \\
\text { Concord }\end{array}$ \\
\hline
\end{tabular}

In line with the table above, it shows that the students have low English proficiency. They made some errors in writing, especially syntactical errors. It is because they did not apply syntactical knowledge appropriately when they were writing in English. As a result, there are some errors were made by the students. The errors became syntactical fossilization because the errors made in the writing 1 and writing 2 .
Some students are not able to use article and pronoun. They are common error among Indonesian learner as there are not equivalents to articles and pronoun in Indonesia. It couldbe said that this type of error classed as L1 transfer. However, it does notreflect a pattern or a rule in Indonesia but merely the presence of aparticular grammatical feature in English and its absence in Indonesia. 
Moreover, using tenses is very difficult for Indonesian students. It is because a tense in Indonesia does not exist. Therefore, Indonesian students are confused in applying tenses when composing sentences in English. This is influenced by first language of the learners, so those are caused syntactic sentence. As a result, they are influenced by their native language in writing English, for instance in the following students' writing performance:

"........ when I was went to metro for a followed the selection of a new student at university.........." (std.3)
"......Then we did read Qur'an test and write Arabic test......" (std. 9)

It illustrated that the students did not apply an appropriate syntactic sentence in their writing. As such, it can be called interlanguage which the language learners use a deviant form from the target language.

\section{b. Morphological Fossilization}

In this research, the writer found some morphological errors in the students' writing performance. It was described in the following table below:

Table 2. Morphological Fossilization in The Students' Writing Performance

\begin{tabular}{|c|c|c|c|c|}
\hline No & Students & Error & $\begin{array}{l}\text { Suggested } \\
\text { Correction }\end{array}$ & Types of error \\
\hline 1 & Std. 1 & $\begin{array}{l}\text { Writing 1: } \\
\text {...... Many * university } \\
\text { with Islamic background } \\
\text { opened. } \\
\text { Writing 2: } \\
\text {..... we can take many } \\
\text { *benefit...... }\end{array}$ & $\begin{array}{l}\text { Writing 1: } \\
\text {...... Many *universities } \\
\text { with Islamic background } \\
\text { opened. } \\
\text { Writing 2: } \\
\text {..... we can take many } \\
\text { *benefits..... }\end{array}$ & Inflection \\
\hline & & $\begin{array}{l}\text { Writing 2: } \\
\text { This definition is written } \\
\text { by me for *help you.... }\end{array}$ & $\begin{array}{l}\text { Writing 2: } \\
\text { This definition is written } \\
\text { by me for *helping you.... }\end{array}$ & Derivation \\
\hline
\end{tabular}


Nurul Aini, Muhammad Khoirul Mufid, Eny Maulita Purnama Sari

\begin{tabular}{|c|c|c|c|c|}
\hline 2 & Std. 2 & $\begin{array}{l}\text { Writing 1: } \\
\text { She always *help me.... } \\
\text { Writing 2: } \\
\text { She always *accompany } \\
\text { me.... }\end{array}$ & $\begin{array}{l}\text { Writing 1: } \\
\text { She always *helps me.... } \\
\text { Writing 2: } \\
\text { She always *accompanies } \\
\text { me... }\end{array}$ & Inflection \\
\hline 3 & Std. 3 & $\begin{array}{l}\text { Writing 1: } \\
\text {.....many *building for } \\
\text { education..... }\end{array}$ & $\begin{array}{l}\text { Writing 1: } \\
\text {....many *buildings for } \\
\text { education...., }\end{array}$ & Inflection \\
\hline & & 10 & Std. 10 & $\begin{array}{c}\text { Writing } 1 \text { : } \\
\text { It took }{ }^{*} \text { very much ours. }\end{array}$ \\
\hline 4 & Std.4 & 10 & Std. 10 & $\begin{array}{c}\text { Writing } 1 \text { : } \\
\text { It took }{ }^{*} \text { very much ours. }\end{array}$ \\
\hline 5 & Std. 5 & $\begin{array}{l}\text { Writing 1: } \\
\text { At the time, I* look at the } \\
\text { couple... } \\
\text { Writing 2: } \\
\text {... Didn't you *repeated } \\
\text { what you did like this. }\end{array}$ & $\begin{array}{l}\text { Writing 1: } \\
\text { At the time, I* looked at } \\
\text { the couple... } \\
\text { Writing 2: } \\
\text {... Didn't you *repeat } \\
\text { what you did like this. }\end{array}$ & Inflection \\
\hline 6 & Std. 6 & \multicolumn{3}{|c|}{ There is not morphological fossilization } \\
\hline 7 & Std. 7 & $\begin{array}{l}\text { Writing 1: } \\
\text { English has given *easy.... } \\
\text { Writing 2: } \\
\text { Her support such as * give } \\
\text { attention more in their } \\
\text { study, * pray to Allah and } \\
\text { etc. }\end{array}$ & $\begin{array}{l}\text { Writing 1: } \\
\text { English has given *easi- } \\
\text { ness... } \\
\text { Writing 2: } \\
\text { Her support such as * giving } \\
\text { attention more in their } \\
\text { study, * praying to Allah } \\
\text { and etc. }\end{array}$ & Derivation \\
\hline
\end{tabular}




\begin{tabular}{|c|c|c|c|c|}
\hline & & $\begin{array}{l}\text { Writing 1: } \\
\ldots \text {, but English also } \\
\text { *need.... } \\
\text { Writing 2: } \\
\text {....She always * protect... }\end{array}$ & $\begin{array}{l}\text { Writing 1: } \\
\text {..., but English also } \\
\text { *needs... } \\
\text { Writing 2: } \\
\text {.... She always * protects... }\end{array}$ & Inflection \\
\hline 8 & Std. 8 & $\begin{array}{l}\text { Writing 1: } \\
\text { I direct to }{ }^{*} \text { going.... } \\
\text { Writing 2: } \\
\text { He also has hobby to }{ }^{*} \text { col- } \\
\text { lection.... }\end{array}$ & $\begin{array}{l}\text { Writing 1: } \\
\text { I direct to }{ }^{*} \text { go.... } \\
\text { Writing 2: } \\
\text { He also has hobby to }{ }^{*} \text { col- } \\
\text { lect... }\end{array}$ & Derivation \\
\hline 9 & Std. 9 & \multicolumn{3}{|c|}{ There is not morphological fossilization } \\
\hline 10 & Std. 10 & \multicolumn{3}{|c|}{ There is not morphological fossilization } \\
\hline
\end{tabular}

The table above shows that morphological fossilization consists of inflection and derivation. In this case, some students did not conduct morphological errors in their writing. They are std.6, std. 9, and std. 10. It means that morphological fossilization is rarely done by students in English writing.

The morphological problems showed that the students made errors in using suffixes, namely past tense inflection, present participle, third singular inflection, plural noun and some derivational suffixes that form noun and verb. The changes involve the absence of suffix which must occur in a well-formed sentence. Moreover, the students performed the presence of suffix that must not appear in the context, and the use of the wrong form of the suffix. In addition, there is no case which involves the absence of infinitive to. In using infinitive to, the students put verb -ing and verb to noun after infinitive.

\section{Causal Factors of Interlanguage Fossilization in the Students' Writing Performance}

In this case, the writer had interviewed 10 students to know the causal factors of interlanguage fossilization in their writing performance. Based on the interview, most of the students answered that writing is difficult subject. They assumed that writing needs many skills to compose a good writing. Actually, when writing English, they are not only having a good competence in exploring their idea, but also they should have a good knowledge in target language. Those reasons can be interpreted from some quotations below:

"Yes, I think writing is difficult because writing needs correct word patterns. In addition, writing expects the writer to be able to influence a reader through our writing."(Std. 3) 
Nurul Aini, Muhammad Khoirul Mufid, Eny Maulita Purnama Sari

"Of course, writing needs cooperation between brain and hand. It is a thought result that delivered into writing, this case requires more carefulness because many principles that must be considered in every writing. For instance, constancy of a word or phrase in every paragraph or related writing" (Std. 4)

Furthermore, the writer had given the question that related interlanguage fossilization in their writing. The question is "What errors do you often conduct in writing? Why is it happened?" From the question, 10 students answered that syntax is errors that often conducted by them. They are unaware that the errors will be interlanguage fossilization. They do the errors in their writing because they have lack of target language knowledge. In the following quotations, the writer chooses some students' answer which they are representative to be displayed.

"Choosing a correct equivalent based on the context, and using structure and grammar. This is caused by inadequacy of vocabulary mastery and confusing toward language transfer from Indonesia into English" (Std. 1)

"The difficulty of English writing is frequently using the same word in writing. I often write word errors in writing and arrange of word based on the correct grammar. Those are caused by incomplete knowledge of the target language" (Std. 9)

It can be drawn conclusion that causal factor of interlanguage fossilization in the students' writing is the students do not mastering of the target language (English). Moreover, they are often influenced by their native language in composing English sentences and over generalized by the target language material especially syntax.

\section{Solution of Interlanguage Fossilization in Students' Writing Performance}

In this case, 10 students had given opinion that interlanguage fossilization in writing can be overcome through a good teaching and learning English. There are some students' suggestions to prevent interlanguage fossilization in their writing, as follows:

"Give more training in writing and guidance toward the errors that often conducted by students in their writing" (Std. 7)

"In my opinion, a teacher or lecturer had better give guiding and understanding for the students in writing. In addition, a teacher or lecturer recommends the students to read a journal frequently, thus the students can look a correct and right writing both in grammar and punctuation"( Std. 3)

It can be concluded that a teacher had better guide more the students to prevent the errors in the students' writing performance. If the errors are ignored, the errors will become interlanguage fossilization. Overcoming interlanguage fossilization is not only duty of a lecturer but also the students have important role in avoiding interlanguage fossilization in their writing. 


\section{DISCUSSION}

In this case, the writer describes the types of interlanguage fossilization in the students' writing performance. Based on the writing 1 and 2, the writer has known the types of interlanguage fossilization that are commonly produced by students' writing performance. They can be shown as the following chart below:

\section{The types of interlanguage fossilization in students' writing performance}

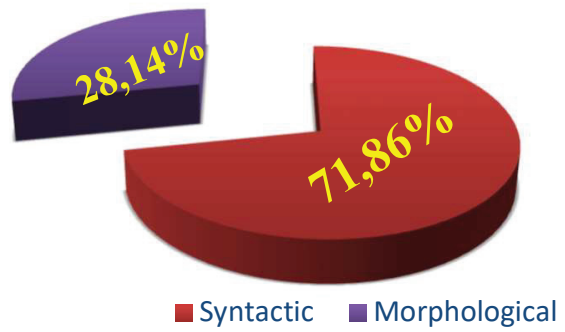

Fi1gure 1. The Types of Interlanguage Fossilization in Students' Writing Performance

The figure above shows two types of interlanguage fossilization in the students' writing performance. They can be classified as follows: $71,86 \%$ (syntactic fossilization) and 28, 14\% (morphological fossilization).

Furthermore, it can be concluded that syntactical fossilization is more common errors than morphological fossilization. Most of the students can not apply their syntactical knowledge appropriately when they compose an essay or paragraph. Moreover, the students assume that writing is a very difficult activity. The students are difficult to express their ideas into written language.
In the students' writing performance, the writer found some errors in syntax. The error caused by unless to syntax. For example: in third singular... God always bless... It would be ... God always blesses... They omit $-s$ after the singular as the errors. This indicate that they are unless in grammar. Similarly, the present participle inflection -ing is added to the basic verb form after the infinitive to: ... to going.... It would be ... to go.... The example is the basic verb. In syntactical errors, for example: in the subject-verb agreement; ... he also as a chief man of Islam... It would be .... He was also as a chief man of Islam.. . In using pronoun, the writer also found errors. For example: ...Afidah and meever went to warnet.... It would be... Afidah and I ever went to warnet...

Those errors were representing of the syntactic errors. It was fossilized by the students in writing English. The facts that the errors would be improved in the next.Therefore, it can be inferred that the students' writing performance are fossilized, but rather they were just temporary fossilization at that particular period of the learning course.

\section{CONCLUSION}

In line with the discussion, it can be concluded that the types of interlanguage fossilization that are commonly produced by students' writing performance of English Education Study Program are syntactical fossilization and morphological fossilization. Syntactic fossilization consists of $71,86 \%$ and morphological fossilization consists of $\mathbf{2 8 , 1 4 \%}$. Syntactical fossilization is more commonly produced by students'. 
Then, the students madeinterlanguage fossilization in their writing performance because of some causal factors. Firstly, the students have not enough knowledge related to English language such as syntax and grammar. Secondly, the students are influenced by their native language when they were writing. Lastly, the students are difficult to explore their ideas in writing. As a result, their writing is not cohesive and coherence yet. There are some strategies to solve interlanguage fossilization in students' writing performance. The teacher should give feedback in teaching writing subject, give a treatment for students who often make errors in writing,and use autonomous learning in teaching writing subject which it leads the students to be an active learners.

\section{References}

Borgias Alip, Francis. (2003). Historical Perspectives in Learning English; Phenomena: Journal of Language and Literature 6 (3), (February, 2003).

Endang Fauziati. (2011). Interlanguage and Error Fossilization: A Study of Indonesian Students Learning English as a Foreign Language; Indonesian Journal of Applied Lingusitics 1 (1), (July,2011).

Huang, Qian. (2009). Probe into the Internal Mechanism of Interlanguage Fossilization; English Language Teaching Vol.2,No.2,( June,2009).

Wei, Xueping. (2008). Implication of IL fossilization in Second Language Acquisition by Chinese College Students; English Language Teaching 1(1), (June, 2008).

Zheng, Yanping. (2010). On Some New Models of Instruction for Overcoming Fossilization in English Learning; Journal of Language Teaching and Research 1(2), (March, 2010).
Brown, H.Douglas. (2001). Teaching by principles: An Interactive Approach to Language Pedagogy $\left(2^{\text {th }}\right.$ edition), San Francisco State University: Longman.

Brown, H.Douglas. (2003).Language Assessment: Principles and Classroom Practices, New York: Longman.

Brown, H.Douglas. (2007). Principles of Language Learning and Teaching (5 $5^{\text {th }}$ edition), San Francisco State University: Pearson Longman.

Brown,H.Douglas. (2000). Principle by Language Learning and Teaching (4th edition), New York: Longman.

Chen, Hongping \& Zhao, Bo. (2013). A Study of Interlanguage Fossilization in Second Language Acquisition and Its Teaching Implications. International Conference on Educational Research and Sports Education. China:Atlantis Press

Cresswell, Jhon W. (2003).Research Design: Qualitative, Quantitative, and Mixed Methods Approach(2nd edition), New Delhi: Sage Publications.

Galuh Nur Rohmah. (2008). Facing the Complexities of Writing, Malang: UIN Malang Press.

Galuh Nur Rohmah. (2009). How to Write Autonomously, Malang: UIN Malang Press.

George E, Wishon \& Julia M.Burks. (1980). Let's Write English, Canada: Van Reinhold Ltd.

Jordan, R.R. (2003). Academic Writing Course, England: Longman.

Kane,ThomasS. (2000). The OxfordEssential Guide to Writing, New York: Berkley Books,.

Kothari,C.R. (2004). Research Methodolgy: Methods and Techniques (2nd Revision), New Delhi: New Age International Publishers.

Maming, Khadijah, Irmayanti Irmayanti, and Rafi'ah Nur. 2019. "Using Wordless Picture Book as a Contributive Learning Media to Enhance the Student's Writing Ability." EDUVELOP 3 (1): 27 34. https://doi.org/10.31605/eduvelop.v3i1.356.

Richards, Jack C. and Richard Schmidt. (2002). Longman Dictionary of Language Teaching \& Applied Linguistics( $3^{\text {rd }}$ edition), Cambridge: Pearson Education Limited. 
Sanggam Siahaan. (2008).Issues in Linguistics, Yogyakarta: Grahallmu.

Saville, Murriel and Troike. (2006). Introducing Second Language Acquisition, (Cambridge: Cambridge University Press.

Singh, Yogesh Kumar. (2006). Fundamental of Research Methodology and Statistics, New Delhi: New Age International Pubishers.
Spolsky, Bernard and Francis M.Hult. (2008). The Handbook of Education Linguistics, Oxford: Blackwell Publishing.

Yin, Robert K. (2011).Qualitative Research from Start to Finish, New York: The Guildford Press.

Dina, A.A. (2017). Students' Fossilized Writing Errors: EFL Postgraduates at Jordanian Universities as a Model. Journal of Al-Quds Opwn University for Research and Studies, No. 19, Part 6, (October 2017) 